\title{
Zagadnienie „ojczyzny w niebie” w Liście św. Pawła do Filipian i w pismach św. Elżbiety od Trójcy Świętej
}

Żegnając się listownie ze swoim lekarzem — doktorem Barbierem², Elżbieta od Trójcy Świętej ${ }^{3}$ pozostawiła mu w darze list ${ }^{4}$ oraz księgę Listów Apostoła Pawła. W liście tym znajdujemy świadectwo jej więzi z Apostołem Narodów oraz jego wpływu na jej młode życie:

Miałam tak wielkie szczęście, iż mogłam widzieć pana, że docenia mojego drogiego świętego Pawła, i dlatego proszę pana, aby dopełnić tego szczęścia, żeby przyjął jako ostatnie pożegnanie od swojej małej pacjentki ostatnie świadectwo jej serdecznej wdzięczności, księgę tych Listów, z których moja dusza czerpała tak wiele siły w tym doświadczeniu. Odnajdziemy się w świetle, które te stronice przynoszą tym, którzy je czytają z wiarą dzieci Bożych.

${ }^{1}$ Ksiądz dr hab. Janusz Wilk (ur. 1973 r.) — kapłan archidiecezji katowickiej, teolog, biblista. Publikacje książkowe z ostatnich lat: Listy Pasterskie. Pierwszy List do Tymoteusza, Drugi List do Tymoteusza, List do Tytusa. Wstep, przektad z oryginatu, komentarz (Katowice 2018); List do Filipian. Wstęp, przektad z oryginatu, komentarz (Katowice 2017); Charakterystyka i zadania przełożonego wspólnoty chrześcijańskiej wedtug Listów Pasterskich. Studium biblijno-pragmatyczne (Katowice 2015); Kapłan jako dobry żotnierz Chrystusa Jezusa. Aspekt biblijno-pastoralny (Katowice 2013); Wierzyć Bogu (Kraków 2011); Pytania z drogi życia (Katowice 2011). Redaktor naukowy serii Biblia Impulsy (j.wilk@katowice.opoka.org.pl). ORCID: 0000-0002-6488-527X.

2 Był on „lekarzem klasztoru” w Dijon.

${ }^{3}$ Elżbieta Catez, ur. 18 lipca 1880 roku we Francji. Do Karmelu w Dijon wstąpiła 2 sierpnia 1901 roku. Zmarła na nieuleczalną wówczas chorobę Addisona 9 listopada 1906 roku. Beatyfikowana 25 listopada 1984 roku, a kanonizowana 16 października 2016 roku.

${ }^{4}$ Zob. L 344 - do lekarza Barbier. W niniejszym opracowaniu opieram się na pismach Elżbiety od Trójcy Świętej, zebranych w: Élisabeth de la Trinité, Euvres Complètes, édition critique C. De Meester, Paris 2017³. Wydanie polskie: Elżbieta od Trójcy Świętej, Pisma wszystkie, t. I: Listy młodzieńcze; t. II: Listy z Karmelu; t. III: Pisma pomniejsze, przekł. i oprac. J.E. Bielecki, Kraków 2006. Numeracja listów (o ile nie zaznaczono inaczej) według przekładu polskiego. Elżbieta była zbyt osłabiona chorobą, aby osobiście napisać ten list, dlatego podyktowała go przeoryszy matce Germanie. Sama, zamiast podpisu, postawiła jedynie mały krzyżyk. Skrót L (przyjęty za skrótami zastosowanymi w dziele Pisma wszystkie ...) oznacza List/Listy. 
Mniszka z Dijon była wierną i gorliwą uczennicą św. Pawła ${ }^{5}$. Obficie czerpała siły i mądrość z jego nauki. Pośród zagadnień, jakie podejmowała w swoich pismach, a które zostały bezpośrednio zaczerpnięte z listów Apostoła Narodów ${ }^{6}$, pragnę w niniejszym opracowaniu podjąć tematykę „ojczyzny w niebie”. Sformułowanie to, zawarte w Liście do Filipian 3,20, w pismach Elżbiety od Trójcy Świętej znalazło się ośmiokrotnie: L 237; 241; 246; 249; 252; 258; 339; ZD $16^{7}$. Każde z tych odniesień będzie stanowić odrębny obszar badawczy tej pracy. W tym celu, korzystając z metody historyczno-krytycznej, dokonam krótkiej analizy Pawłowego stwierdzenia „,nasza ojczyzna jest w niebie” (Flp 3,20), by następnie przez studium opisowe ${ }^{8}$, ukazać zastosowanie tego sformułowania w piśmiennictwie św. Elżbiety: jego formę lingwistyczną, kontekst oraz celowość zamieszczenia go w danym piśmie.

\section{Zagadnienie „ojczyzny w niebie” w Liście św. Pawła do Filipian 3,20}

Zanim przejdziemy do bezpośredniego spojrzenia na zagadnienie „niebiańskiej ojczyzny" w Flp 3,20, trzeba wpierw — przynajmniej w zarysie — przyjrzeć się adresatom tego listu. Gdy wiemy, do kogo zwracał się św. Paweł, wymowniejsze staje się znaczenie tego sformułowania.

Społeczeństwo Filippi ${ }^{9}$ w czasie powstania Listu św. Pawła do Filipian nie stanowiło jedności etniczno-kulturowej. Wyróżnia się w nim dwie grupy ludności. Pierwsza to mieszkańcy niezwiązani ze środowiskiem rzymskim (Mace-

5 Zob. J.K. Miczyński, La lettura spirituale dell'insegnamento di San Paolo Apostolo negli scritti di Elisabetta della Trinità, „Spiritualitas” 1 (2014), s. 217-230; A. Vella, Bl. Elizabeth of the Trinity: Disciple of St. Paul, „Carmel in the World” 24 (1985), s. 207-216.

${ }^{6}$ Ich indeksację zob.: Elżbieta od Trójcy Świętej, Pisma wszystkie, t. III: Pisma pomniejsze..., s. 485-490. Zob. także T.M. Dąbek, Biblia w duchowości bł. Elżbiety od Trójcy Przenajświętszej [w:] ,, Uwielbienie chwały”. VI Karmelitański Tydzień Duchowości z bt. Elżbietą od Trójcy Świętej. 5-8 maja 2003, red. J.W. Gogola, (Karmel Żywy 6), Kraków 2004, s. 33-49.

7 W wykazie odnośników biblijnych w: Elżbieta od Trójcy Świętej, Pisma wszystkie, t. III: Pisma pomniejsze..., s. 489, wskazano osiem pism, gdzie znajduje się odniesienie do Flp 3,20. Jednakże błędnie znalazł się tam L 259, a zabrakło L 258. Skrót ZD (przyjęty za skrótami zastosowanymi w dziele Pisma wszystkie...) oznacza Zapiski duchowe.

${ }^{8}$ Por. J. Słomka, Metodologia teologii duchowości, ,Śląskie Studia Historyczno-Teologiczne" 50 (2017) 1, s. 129-142, tu: s. 138.

${ }^{9}$ Filippi (gr. Filippoi łac. Philippi) to starożytne miasto we wschodniej Macedonii, obecnie na terytorium Grecji. Usytuowane na północnym wybrzeżu Morza Egejskiego, pomiędzy miastami Neapolis od wschodu (ok. 15 km; dziś ruchliwy port Kawala), a Amfipolis od zachodu (ok. 50 km; dziś już tylko ruiny antycznego miasta, nowa osada na tym terenie to Neochori). Na miejscu pozostały jedynie ruiny świadczące o minionych już latach świetności, gdyż miasto zostało opuszczone w średniowieczu na skutek panującej w nim malarii; zob. J. Wilk, ,, Teologia kontaktu” na podstawie Listu św. Pawła do Filipian i Dziejów Apostolskich 16, (Studia i Materiały Wydziału Teologicznego Uniwersytetu Śląskiego w Katowicach 31), Katowice 2006, s. 24. 
dończycy, Grecy, Trakowie oraz ludność napływowa, pośród której była również niewielka liczba Żydów). Drugą stanowili mieszkańcy wywodzący się ze środowiska rzymskiego (potomkowie weteranów Legionu XXVIII, kohorta pretoriańska oraz osadnicy z Italii) ${ }^{10}$. Miasto było zdominowane przez środowisko rzymskie, głównie wywodzące się ze środowisk militarnych, tworzących rzymską administrację miasta. Przewaga liczebna tej ludności ${ }^{11}$ oraz porządek i prawo rzymskie spowodowały, że Filippi można było określić mianem „przedmieście Rzymu"12. Paweł, pisząc list do chrześcijan tego miasta, precyzyjnie posłużył się terminologią, która umożliwiała mieszkańcom tej rzymskiej kolonii (Colonia Augusta Iulia Vitrix Philippensium) ${ }^{13}$ właściwie zrozumieć prawdy teologiczne. Zagadnienie „niebiańskiej ojczyzny” jest jednym z przykładów kunsztu literackiego Apostoła Narodów.

\title{
1.1. Propozycja przekladu Flp 3,17-21 ${ }^{14}$
}

\begin{abstract}
${ }^{17}$ Bracia, stawajcie się moimi współnaśladowcami i przypatrujcie się tym, którzy tak postępują, jak wzór tego macie w nas. ${ }^{18}$ Wielu bowiem zachowuje się — jak to już wam wielokrotnie mówiłem, a teraz powtarzam, płacząc — jak wrogowie krzyża Chrystusa. ${ }^{19}$ Ich końcem — zatracenie, ich bogiem — brzuch, a chwała ich w tym, czego należy się wstydzić. Ich myślenie zatrzymuje się tylko na rzeczach ziemskich. ${ }^{20}$ Tymczasem nasza ojczyzna (politeuma) jest w niebie. Stamtąd wyczekujemy Zbawiciela - Pana Jezusa Chrystusa, ${ }^{21}$ który przekształci ciało naszego upokorzenia w podobne do ciała Jego wywyższenia, zgodnie z potęgą, którą wszystko może On sobie podporządkować.
\end{abstract}

\subsection{Ogólna prezentacja kontekstu Flp 3,20}

Sformułowanie „nasza ojczyzna jest w niebie” (Flp 3,20) znajduje się w głównej części listu (corpus: 1,12-4,1), w passusie dotyczącym aktywności fałszywych nauczycieli $(3,1 b-4,1)^{15}$. Celem tej sekcji było ostrzeżenie chrześcijan w Filippi przed

${ }^{10}$ Por. tamże, s. 35-39.

${ }_{11}$ Prawdopodobnie pod koniec I wieku po Chrystusie w Filippi żyło od 5000 do 10000 mieszkańców. Miasto to było stale zasilane przez nowych weteranów; zob. P. Pilhofer, Philippi, Bd. I: Die erste christliche Gemeinde Europas, (Wissenschaftliche Untersuchungen zum Neuen Testament 87), Tübingen 1995, s. 76.

12 E. Dąbrowski, Święty Pawet. Życie i pisma, Poznań $1952^{2}$, s. 77.

13 Por. P. Pilhofer, Philippi, Bd. II: Katalog der Inschriften von Philippi, (Wissenschaftliche Untersuchungen zum Neuen Testament 119), Tübingen 2000, s. 4, nr 004/L030; A. Jankowski, Listy więzienne świętego Pawła. Do Filipian - do Kolosan - do Filemona - do Efezjan. Wstęp, przekład z oryginatu, komentarz, (Pismo Święte Nowego Testamentu VIII), Poznań 1962, s. 37-38.

${ }_{14}$ Przekład własny na podstawie: Novum Testamentum Graece, ed. E. Nestle et al., Stuttgart $2012^{28}$.

${ }^{15}$ List do Filipian otrzymał całą gamę opracowań struktury. Jest to związane zarówno z jego treścią, jak i hipotezami dotyczącymi wielu listów zawartych w tym piśmie; zob. np.: G.F. Ha- 
działalnością oponentów Ewangelii. Apostoł Paweł, używając języka metafory, dokonał najpierw ich charakterystyki (w. $1 \mathrm{~b}-4 \mathrm{a})^{16}$, a następnie $\mathrm{w}$ formie periautologii odniósł się do własnego życia (w. 4b-16) ${ }^{17}$, by zamknąć passus dwuaspektową opinią: negatywną (w. 18-19) i pozytywną (w. 20-21). Zastosowanie spójnika gar (,bowiem”; w. 20), podkreśla związek wersetów 20-21 z poprzednią myślą, chociaż przedstawioną w całkiem odmiennym świetle. Wypowiedzi ramowe tego passusu $(3,17$ i 4,1) zawierają zachętę, wyrażoną w drugiej osobie liczby mnogiej. „Niebiańska ojczyzna” wiąże się zatem z pozytywną stroną życia.

\subsection{Znaczenie leksemu politeuma w Flp 3,20}

Rzeczownik politeuma należał do podstawowego wokabularza społeczno-politycznego antyku. Jego pole semantyczne zawiera terminy z kilku grup znaczeniowych: 1. „rządzenie”; ,akt administracyjny”; 2. „rząd”, „władze państwowe”, „ustrój”; 3. „prawa obywatelskie”, „obywatelstwo”; 4. „państwo”, „ojczyzna”, „wspólnota" ${ }^{18}$. Leksem ten stanowi hapax legomenon $\mathrm{NT}^{19}$.

W zastosowaniu tego leksemu w Flp 3,20 można dostrzec:

1. „Wspólnotę”, „państwo w niebie”. Chrześcijanie, chociaż żyją jeszcze na ziemi, de facto są już „obywatelami nieba”. Zwrot ten podkreśla pewną

wthorne, R.P. Martin, Philippians, (Word Biblical Commentary 43), Nashville 2004², s. LVIIILIX; B. Byrne, List do Filipian [w:] Katolicki komentarz biblijny, red. nauk. wyd. oryginalnego R.E. Brown, J.A. Fitzmyer, R.E. Murphy, red. nauk. wyd. polskiego W. Chrostowski, thum. K. Bardski i in., (Prymasowska Seria Biblijna 17), Warszawa 2001, s. 1399-1408, tu: s. 1401; H. Langkammer, List do Filipian. Ttumaczenie, wstęp i komentarz, (Biblia Lubelska), Lublin 2001, s. 22; A. Jankowski, Listy więzienne świętego Pawła..., s. 67-68. W kwestii budowy Listu do Filipian warto zapoznać się z monografią P. Wick, Der Philipperbrief. Der formale Aufbau des Briefs als Schlüssel zum Verständnis seines Inhalts, (Beiträge zur Wissenschaft vom Alten und Neuen Testament 135), Stuttgart-Berlin-Köln 1994.

16 Zob. J. Wilk, Wartości figuralne metafor w Pawłowym Liście do Filipian (3,2), „Ateneum Kapłańskie" 162 (2014) 1 (629), s. 95-104.

17 Zob. F. Bianchini, L'elogio di sé in Cristo. L'utilizzo della periautologi, a nel contesto di Filippesi 3,1-4,1, (Analecta Biblica 164), Roma 2006.

${ }_{18}$ Por. politeuma w: Słownik grecko-polski, red. Z. Abramowiczówna, Warszawa 1962, t. III, s. 575 [dalej: SGP]; R. Popowski, Wielki stownik grecko-polski Nowego Testamentu. Wydanie z petna lokalizacja greckich haset, kluczem polsko-greckim oraz indeksem form czasownikowych, (Prymasowska Seria Biblijna 3), Warszawa 1995², s. 512; U. Hutter, politeuma [w:] Exegetisches Wörterbuch zum Neuen Testament, Bd. III, hrsg. v. H. Balz, G. Schneider, Stuttgart-Berlin-Köln $1992^{2}$, kol. 310-312.

${ }^{19}$ W LXX występuje on w 2 Mch 12,7. Z rzeczownikiem tym spokrewniony jest czasownik politeuomai („,być obywatelem”; „Żyć w wolnym państwie”), zob. politeuomai w: SGP, s. 575. Został on wykorzystany w Dz 23,1 i w Flp 1,27. Tekst zawarty w Flp 1,27 stanowi pewną formę wprowadzenia do myśli zawartej w Flp 3,20. Zob. także E.C. Miller, Politeu,esqe in Philippians 1,27: Some philological and thematic observations, „Journal for the Study of the New Testament” 15 (1982), s. 86-96. 
obcość wobec tego, co ziemskie, i równocześnie akcentuje bliskość wobec tego, co niebiańskie ${ }^{20}$.

2. „Prawa obywatelskie”. Niebo jest miejscem, gdzie wyznawcom Chrystusa będą przysługiwać prawa, których często byli pozbawieni w świecie ${ }^{21}$.

3. Kontrast politeuma wobec tego, co epigeios (,ziemskie”; „doczesne”; ,żyjący na ziemi"; zob. np.: J 3,12; Flp 3,19). Celem zastosowania tego terminu byłoby wyeksponowanie prawdy, że chrześcijanie należą do państwa znajdującego się w niebie, a na którego obszarze jeszcze nie mieszkają ${ }^{22}$.

Na podstawie tych interpretacji możemy ustalić, że cecha semantyczna tego leksemu związana jest z przestrzenią życia obywatelskiego i wiąże się z terminami: „państwo”, „ojczyzna” oraz „prawa obywatelskie”. Nie są to jednak terminy synonimiczne ${ }^{23}$. Apostoł Paweł nie musiał jednak precyzować znaczenia tego leksemu. Wśród chrześcijańskich mieszkańców Filippi był on wystarczająco czytelny i co najważniejsze — przejrzysty w swoim przesłaniu. Obywatele rzymscy — przyjmując chrześcijaństwo - niejednokrotnie tracili możliwość korzystania z przywilejów, które dawało im Civis Romanus. W praktyce oznaczało to brak aktywnego uczestniczenia w życiu społeczno-kulturalno-administracyjnym imperium rzymskiego, gdyż większość wydarzeń związanych z tymi aspektami życia oraz urzędów administracji państwowej wiązała się z koniecznością oddania czci bóstwom opiekuńczym i wyrażenia czci boskiemu cezarowi ${ }^{24}$.

Apostoł Narodów przeniósł pojęcie „bycia obywatelem” — fundamentalną myśl kultury grecko-rzymskiej — na sferę duchową. Chciał wzmocnić chrześci-

${ }^{20}$ Por. U.B. Müller, Der Brief des Paulus an die Philipper, (Theologischer Handkommentar zum Neuen Testament 11/I), Leipzig $2002^{2}$, s. 182. Prawdopodobnie u schyłku II wieku po Chrystusie nieznany nam autor doskonale scharakteryzował chrześcijan: „mieszkają każdy we własnej ojczyźnie, lecz niby obcy przybysze. Podejmują wszystkie obowiązki jak obywatele i znoszą wszystkie ciężary jak cudzoziemcy. Każda ziemia jest im ojczyzną i każda ojczyzna ziemią obcą. Żenią się jak wszyscy i mają dzieci, lecz nie porzucają nowo narodzonych. Wszyscy dzielą jeden stół, lecz nie jedno łoże. Są w ciele, lecz nie żyją według ciała. Przebywają na ziemi, lecz są obywatelami nieba" — Do Diogneta, V,5-9, w: Pierwsi świadkowie. Pisma Ojców Apostolskich, tłum. A. Świderkówna, wstęp, kom. i oprac. M. Starowieyski, (Biblioteka Ojców Kościoła 10), Kraków $2010^{2}$ (uzupełnione i poprawione), s. 342.

${ }^{21}$ Por. A. Świderkówna, Biblia w świecie greckim, (Radiowa Katecheza Biblijna 5), Gniezno 1996, s. 178; P.Ch. Böttger, Die eschatologische Existenz der Christen. Erwägungen zu Philipper 3,20, „Zeitschrift für die neutestamentliche Wissenschaft und die Kunde des Urchristentums” 60 (1969), s. 244-263, tu: s. 244.

${ }^{22}$ Por. M. Dibelius, Die Briefe des Apostels Paulus. An die Thessalonicher I. II. An die Philipper, (Handbuch zum Neuen Testament III/2), Tübingen 1911, s. 61.

${ }^{23}$ Człowiek może żyć w państwie, które nie jest jego ojczyzną. Może on również posiadać prawa obywatelskie w innym państwie, a być ich pozbawionym w ojczyźnie. Zob. także P. Pilhofer, Philippi, Bd. I, s. 129.

${ }^{24}$ Por. S. Mędala, Świadectwo mocy Chrystusa (List do Filipian) [w:] Wprowadzenie w myśl i wezwanie ksiag biblijnych, t. IX: Dzieje Apostolskie. Listy św. Pawła, red. J. Frankowski, współred. S. Mędala, Warszawa 1997, s. 381-411, tu: s. 403-404. 
jan w Filippi, którzy jako rzymscy obywatele tego miasta wyróżniali się spośród wszystkich jego mieszkańców przez swoją pełnoprawną przynależność do Colonia Augusta Iulia Vitrix Philippensium. Podobnie też, jako chrześcijanie, wyróżniali się spośród całej społeczności mieszkańców Filippi przez swoją przynależność do „niebiańskiej ojczyzny”25. Jednakże owo ,już” „niebiańskiej ojczyzny” jest jednocześnie ,jeszcze nie"26. Chociaż cel jest już widoczny, to jednak droga do niego wciąż pozostaje aktualnym trudem.

\section{Zagadnienie ,ojczyzny w niebie” w pismach św. Elżbiety od Trójcy Świętej}

Wszystkie odniesienia do „niebiańskiej ojczyzny”, które znajdują się w zachowanych pismach Elżbiety Catez (L 237; 241; 246; 249; 252; 258; 339; ZD 16), zostały napisane po 2 sierpnia 1901 roku, czyli po jej wstąpieniu do Karmelu w Dijon. Po raz pierwszy odniosła się do tego zagadnienia 1 sierpnia 1905 roku (L 237), a po raz ostatni 28 października 1906 roku (L 339).

\section{1. „Nasze życie jest w niebie"27 (L 237)}

W liście tym, adresowanym do ciotek Rolland ${ }^{28}$, sformułowanie „nasze życie jest w niebie" stanowi motto (nagłówek) listu.

To jej dziesiąty (przedostatni) list do obydwu ciotek $^{29}$. Autorka nie podejmuje w nim żadnych zagadnień eschatologicznych. Po prostu ,przychodzi do nich do Carlipa z małymi odwiedzinami” z okazji święta (odpustu) patrona parafialnego

${ }^{25}$ Por. J. Wilk, List do Filipian. Wstę, przekład z oryginatu, komentarz, (Biblia Impulsy XI), Katowice 2017, s. 37; tenże, „, Teologia kontaktu”..., s. 158; L. Portefaix, Sisters Rejoice: Paul's Letter to the Philippians and Luke - Acts as Seen by First-Century Philippian Women, Uppsala 1988, s. 139.

${ }^{26}$ Por. J. Flis, List do Filipian. Wstep, przektad z oryginatu, komentarz, (Nowy Komentarz Biblijny. Nowy Testament XI), Częstochowa 2011, s. 389; G.D. Fee, Paul's Letter to the Philippians, (The New International Commentary on the New Testament), Grand Rapids (MI)-Cambridge 1995, s. 379.

${ }^{27}$ Tekst oryginału: ,[n]otre vie est dans les Cieux” (L 235). Teksty oryginalne w języku francuskim za: Élisabeth de la Trinité, Euvres Complètes... Polska numeracja pism Elżbiety od Trójcy Świętej nie pokrywa się z numeracją francuską. Szczegółowego zestawienia numeracji pism siostry Elżbiety w wydaniu polskim, francuskim i włoskim dokonał J.K. Miczyński; zob. A.M. Sicari, Elżbieta od Trójcy Świętej, tłum. A. Bałucka-Grimaldi, Kraków 2007, s. 319-323.

${ }^{28}$ Dwie siostry: Matylda (ur. 24 lutego 1858) i Franciszka (ur. 10 grudnia 1859), niezamężne kuzynki matki Elżbiety. Mieszkały wraz z matką w Carlipa. Matka - Katarzyna Saignes — była ciotką Marii Catez. Zob. ich fotografię w: Elżbieta od Trójcy Świętej. O świcie Ciebie szukam. Wspomnienie pewnego oblicza i pewnego serca, red. P.P. Furdzik, Kraków 2006, s. 52, nr 114.

${ }_{29}$ Zob. Listy wspólne dla obydwu ciotek: L 78; 91; 109; 155; 163; 172; 188; 200; 218; 237; 260. Listy do jednej z nich: L 138 (Do ciotki Frani); L 140 (Do ciotki Matyldy). 
kościoła — św. Piotra w Okowach. Wspomina swoje wcześniejsze wizyty w tym kościele oraz relacjonuje życie rodzinne (matka, siostra i jej dwie córki) i zakonne (wydarzenia związane ze wspomnieniem św. Marty). Zapewnia swoje krewne o modlitwie, przez którą chce wyprosić im „najsłodsze błogosławieństwa”.

Elżbieta, pisząc o aktualnych sprawach osób sobie najbliższych, przez nagłówek listu (zFlp 3,20) pośrednio odniosła wszystkie te sprawy do rzeczywistościnieba. W tego rodzaju spojrzeniu Elżbiety można dostrzec kontynuację wydarzeń codzienność ziemskiego życia płynie ku codzienności życia w niebie.

\section{2. „Nasze życie jest w niebie" ${ }^{\text {30 }}$ (L 241)}

Adresatką listu, w którym znalazły się te Pawłowe słowa, była rodzona siostra Elżbiety - Małgorzata $^{31}$. List ten należy do jednych z dłuższych listów, jakie napisała Mistyczka z Dijon. Po krótkim wstępie, zawierającym informację o niedzielnej adoracji Najświętszego Sakramentu, Elżbieta podejmuje zagadnienia dotyczące bezpośrednio Małgorzaty, jej dwóch córek (Elżuni i Odetki) oraz zmęczenia, które od pewnego czasu towarzyszy młodej mamie. W tym kontekście wprowadza ją w myśli św. Pawła Apostoła. Korzysta z: Ef 1,4-6; Rz 8,17; Kol 1,12 i ponownie Ef 2,19. Cały ten ciąg myślowy, którego punktem wyjściowym były dzieci Małgorzaty, prowadzi od kwestii dziecięctwa Bożego, czyli Bożej adopcji człowieka (Ef 1,4-6), zagadnienia dziedzictwa (Rz 8,17), aż po uzdolnienie człowieka, aby mógł uczestniczyć w dziele świętych i był domownikiem Boga (Kol 1,12; Ef 2,19). Podsumowuje te myśli interesującym nas sformułowaniem „nasze życie ${ }^{32}$ jest w niebie”, dodaje komentarz: „och, moja Gosiu, to niebo, ten dom naszego Ojca jest «centrum naszej duszy»!”. Elżbieta od Trójcy Świętej czerpie z myśli św. Pawła dotyczącej przyszłości, ale odnosi ją do teraźniejszości. Już tu na ziemi, dzięki łasce Boga wynikającej z daru chrztu, człowiek posiada możliwość utworzenia w swojej duszy „sanktuarium”, w którym Bóg może uczynić niebo, czyli zamieszkać w głębi ludzkiej duszy ${ }^{33}$.

30 Tekst oryginału: „notre vie est dans les Cieux” (L 239).

${ }^{31}$ Urodzona 20 lutego 1883 roku, zmarła 7 maja 1954 roku. Podobnie jak Elżbieta była uzdolnioną pianistką. 15 października 1902 roku zawarła związek małżeński z Jerzym Chevignardem. Doczekali się dziewięciorga dzieci; zob. więcej: J. Rémy, Guite. La sorella di Elisabetta della Trinità, trad. L.Ceccon Terranova, Milano 2004.

${ }^{32}$ W liście tym polski tłumacz przełożył rzeczownik „vie” terminem „obcowanie”. Choć poprawnie, bardziej uzasadniony jest tego rodzaju przekład wtedy, kiedy siostra Elżbieta posługuje się terminem „conversatio”.

${ }^{33}$ Por. J.D. Szczurek, Tajemnica zamieszkania Trójcy Świętej $w$ duszy wedlug bł. Elżbiety w Dijon [w:] Niebo w mej duszy. Materiały z sympozjum poświęconego duchowości bt. Elżbiety od Trójcy Świętej (1880-1906) w stulecie jej śmierci. Kraków, 21 listopada 2006 r., red. A. Ruszała, Kraków 2007, s. 27-44, tu: s. 34. 
Elżbieta z Dijon doskonale łączy kwestię „nieba” ze sprawami „ziemi”. Stąd w dalszej części tego listu poruszy jeszcze sprawę mamy oraz miesięcznych rekolekcji, na które „zaprosi” również Małgorzatę. W postscriptum doda: „mój list tylko dla nas dwóch". Małgorzata żyje pośród wielu osób. W tym ruchliwym świecie Elżbieta zaprasza ją, aby żyła w „mieszkaniu wewnętrznym”. Tam jest przestrzeń dla nieba, czyli miejsca, gdzie jest Bóg.

\section{3. „Nasze życie jest w niebie" ${ }^{94}$ (L 246)}

Elżbieta od Trójcy Świętej sformułowanie „nasze życie jest w niebie” zamieściła również w liście do ks. Andrzeja Chevignarda ${ }^{35}$. To jej przedostatni z trzynastu listów do tego kapłana i równocześnie pierwszy, w którym znalazła się myśl św. Pawła z Flp 3,20. Autorka listu zamieszcza ją jako motto całego pisma, nie rozwijając jej w dalszych wersetach.

Myślą przewodnią tego pisma jest prośba siostry Elżbiety, która rozpoczyna „długą podróż”, czyli dziesięciodniowe rekolekcje osobiste, aby ks. Chevignard „wiele za nią się modlił”. Prosi nade wszystko o „wielką intencję w Najświętszej Ofierze”. Gdy spojrzymy na ten list, oddzielając go od całej epistolografii Elżbiety, dostrzegamy w nim tylko prośbę karmelitanki i równocześnie zapewnienie młodego kapłana o jej stałej modlitwie ${ }^{36}$. Tymczasem odnosząc się do innych jej listów ${ }^{37}$, widzimy w niej wrażliwość mistyczki, która pragnie jak najlepszego skupienia, aby mogła być ze swoim Bogiem. Ta „długa podróż”, jak sama nazwała rekolekcje, to wędrowanie w głąb duszy. Tam oczekuje jej Bóg ${ }^{38}$.

34 Tekst oryginału: „notre vie est dans les Cieux” (L 244).

${ }^{35}$ Brat jej szwagra Jerzego. Urodził się w Paryżu 2 stycznia 1879 roku. Wstąpił do seminarium w Dijon 1 października 1900 roku. Święcenia kapłańskie przyjął w katedrze w Dijon 29 czerwca 1905 roku z rąk bpa Mailleta z Saint-Claude. W piątek 30 czerwca, w Uroczystość Najświętszego Serca Pana Jezusa, odprawił swoją pierwszą Mszę Świętą w Karmelu w Dijon. Zmarł 10 marca 1949 roku w Nuits-Saint-Georges; zob. L'abbé André Chevignard, 3 października 2017, [online] http://www.elisabeth-dijon.org/fr/accueil/95-cat\%C3\%A9gories-all/cat\%C3\%A9gories-fr/personnes/259-abb\%C3\%A9-chevignard.html [15.11.2018].

36 „Z mojej strony nie mówię księdzu, że będę się za księdza modlić, to jest zbyt oczywiste, a nade wszystko od 30 czerwca [dzień pierwszej Mszy św. odprawionej w Karmelu] mogę powiedzieć, że moja dusza skłania się ku temu zupełnie naturalnie".

${ }^{37}$ Np. do L 170 - Do księdza kanonika Angles.

38 Por. M.M. Philipon, Trójca Święta w moim życiu. Doktryna duchowa Siostry Elżbiety od Trójcy Przenajświętszej, tłum. siostra dominikanka z klasztoru św. Anny, siostra benedyktynka od nieustającej adoracji, Poznań $2002^{2}$, s. 75. 


\section{4. „Nasze życie jest w niebie" ${ }^{939}$ (L 249)}

Dziękując za czekoladki, które Elżbieta od Trójcy Świętej otrzymała z okazji swoich imienin ${ }^{40}$ od Marii Luizy de Sourdon ${ }^{41}$ (w tak ładnym pudełku, że „naprawdę szkoda go dotykać”!), ponownie odnosi się do myśli św. Pawła z Flp 3,20. Tym razem stosuje ten biblijny fragment, aby wyraźnie oddzielić dwie rzeczywistości: ziemską i niebiańską. Wychwalając ofiarodawczynię za jej talenty cukiernicze, informuje ją o modlitwie do św. Teresy od Jezusa ${ }^{42}$ „o najbardziej szczególną opiekę i nagłą pomoc dla miłej ciastkarki, która tak rozpieszcza jej córki w Karmelu". Jednocześnie wyraźnie zaznacza ${ }^{43}$, że życie karmelitanki, chociaż przeżywane jeszcze na ziemi, dotyka już nieba. Dla Elżbiety najlepszym tekstem wyrażającym ten stan jest właśnie wypowiedź z Flp 3,20: „nasze życie jest w niebie”. Troska o niebo nie przeszkadza Mistyczce z Dijon i całej jej wspólnocie ,interesować się tymi, którzy są na ziemi”. Człowiek wrażliwy na wieczność jest również wrażliwy na doczesność. Niekoniecznie odwrotnie.

\section{5. „Nostra autem conversatio in coelis est”44 (L 252)}

To ostatni z trzynastu listów, które otrzymał najpierw jako kleryk, a następnie jako kapłan Andrzej Chevignard od siostry Elżbiety od Trójcy Świętej. Interesujące nas zdanie z Flp 3,20 znalazło się zaraz na początku listu i to w wersji łacińskiej. Mistyczka z Dijon wprowadza czytelnika w tę wypowiedź: „dopiero co przeczytałam u świętego Pawła te oto proste słowa, a równocześnie bardzo głębokie: «Nostra autem conversatio in coelis est»»" Nie oznacza to, że dopiero co je odkryła w Corpus Paulinum, ale że ponownie do nich

39 Tekst oryginału: „notre vie est dans les Cieux” (L 247).

${ }^{40}$ Wspomnienie św. Elżbiety Węgierskiej, patronki Mistyczki z Dijon, przypada 17 listopada.

${ }^{41}$ Starsza córka hrabiny Małgorzaty Sourdon. W domu hrabiny w Gemeaux rodzina Catez spędzała wakacje. Zob. ich fotografię w: Elżbieta od Trójcy Świętej. O świcie Ciebie szukam..., s. 49 , nr 20 .

${ }^{42}$ Elżbieta, w swoich pismach, odwołując się do Teresy z Ávila, nie stosuje jej predykatu („od Jezusa”), gdyż nie było wówczas takiej potrzeby. Teresa od Dzieciątka Jezus (zmarła 30 września 1897 roku), nie została jeszcze ogłoszona świętą.

${ }^{43}$ Elżbieta zastosowała spójnik ,quoique” (,chociaż”; „choć”; „mimo że”), który wskazuje na kontrast, rozbieżność między tym, co się dzieje, a tym, czego można było oczekiwać.

${ }^{44}$ Elżbieta od Trójcy Świętej cytuje w tym liście tekst Flp 3,20 z Wulgaty. Wersja oryginalna tego listu, to L 250. Przekład „,nostra autem conversatio in coelis est” brzmi: „,nasze zaś obcowanie/ wspólny pobyt jest w niebie". Zob. także: Biblia Sacra iuxta vulgatam versionem, ed. B. Fischer et al., Stuttgart $1994^{4}$. 
powróciła ${ }^{45}$. Nieustannie karmi się myślą Apostoła Narodów ${ }^{46}$ i dzieli się nią $\mathrm{z}$ bratnią duszą kapłana.

W liście tym Elżbieta od Trójcy Świętej rzeczywistość nieba postrzega jako już aktualną. To w niej może spotkać się z Trójjedynym Bogiem, ale i z tymi, którzy wraz z nią ,pójdą" w wierze w tym samym kierunku. Tego rodzaju interpretacji jej myśli sprzyja również łaciński leksem „conversatio”, który w swoim polu semantycznym oprócz terminu „obcowanie” mieści następujące słowa: „wspólny pobyt”, „zażyłość”; „towarzystwo”47. Jego cechą semantyczną jest „bycie ze sobą”. „Niebo” dla s. Elżbiety to dzięki Bożej łasce i wierze doświadczenie już aktualne, które najpełniej będzie przeżywać po swojej śmierci ${ }^{48}$.

Dzieląc się z ks. Chevignardem swoją lekturą Biblii, układa przed nim mozaikę myśli opartych na słowach Pisma Świętego (Ef 2,19; Kol 3,3; Ps 18,5-7; 96,3; J 8,25.26; 17,2.10; Ga 2,20; Hbr 12,29; Kol 1,24), by pod koniec listu po raz pierwszy określić siebie jako „Laudem gloriae” (Ef 1,12) ${ }^{49}$. Opisuje swoje doświadczenie duchowe, które jeszcze mocniej ją mobilizuje, aby odłączyć się od tego wszystkiego, co nie jest związane z Jezusem. Pragnie pozbyć się z duszy wszelkich spraw, które mogą ograniczać miejsce Jezusowi.

Pisząc o swoim pojmowaniu adwentu, Elżbieta z Dijon poleca siebie modlitwom księdza Chevignarda. Ma ku temu szczególną okazję. Zbliża się uroczystość Niepokalanego Poczęcia Najświętszej Maryi Panny (8 grudnia), a dla niej to także czwarta rocznica obłóczyn. Prosząc o poświęcenie jej „mocy miłości Jezusa", sama zapewnia młodego wikariusza z Meursault o modlitwie w jego intencji. Poruszając w tym liście kwestię nieba, realistycznie spogląda na sprawy ziemi. Wie, że czystość duszy umożliwia Chrystusowi zamieszkanie w człowieku. A tam, gdzie jest Chrystus, tam jest niebo.

${ }^{45}$ W swoich wcześniejszych listach już czterokrotnie cytowała Flp 3,20. Niespełna dwa miesiące wcześniej słowa te stanowiły nagłówek do poprzedniego listu, adresowanego do ks. Chevignarda (L 246).

${ }^{46}$ Zob.: L 192; 193; 232; 241; 251; 266; 301; 308; 343.

${ }^{47}$ Zob. Stownik tacińsko-polski, red. J. Korpanty, Warszawa 2001, t. I, s. 443.

${ }_{48}$ Dla przykładu zob.: L 105; 108; 121; 123; 134; 140; 144; 166; 170; 183; 193; 195; 201; 212; $237 ; 241 ; 251 ; 254 ; 271 ; 273 ; 276 ; 282 ; 286 ; 290 ; 293 ; 299 ; 300 ; 306$. Zob. także: T. Nawracała, Louange de la gloire - la vie de l'homme cachée dans la Trinité, „Poznańskie Studia Teologiczne” 24 (2010), s. 215-234; tenże, Les fines dernières chez la b. Elisabeth de la Trinité, „Wrocławski Przegląd Teologiczny" 17 (2009) 2, s. 61-76.

49 Elżbieta od Trójcy Świętej wykorzystała tę myśl, pisząc do ks. Chevignarda już w L 192: „[j]ednoczmy się dla Niego [Boga], aby na mocy miłości zapomnieć o wszystkim i bądźmy, jak mówi święty Paweł «uwielbieniem Jego chwały» (tekst oryginalny — L 191: «la louange de sa gloire»)". W L 252, po raz pierwszy w formie łacińskiej, odnosi to wyrażenie bezpośrednio do siebie. Niebawem stanie się ono jej „drugim imieniem”. Zob. omówienie tego wyrażenia w: Elżbieta od Trójcy Świętej, Pisma wszystkie, t. II, s. 364, przyp. 17; K.W. Kraj, Laudem gloriae życie codzienne jako liturgia [w:] ,, Uwielbienie chwały”. VI Karmelitański Tydzień Duchowości z bl. Elżbieta od Trójcy Świętej. 5-8 maja 2003, red. J.W. Gogola, (Karmel Żywy 6), Kraków 2004, s. $155-181$, tu: s. $163-174$. 


\section{6. „Nasze obcowanie jest w niebie" ${ }^{50}$ (L 258)}

Pawłową myśl z Flp 3,20 siostra Elżbieta skierowała także do ks. kanonika Emiliana Izydora Angles ${ }^{51}$ — swojego powiernika „od zawsze" ${ }^{2}$. Posłużyła się nią, aby „wytłumaczyć się” ze swojego dłuższego (listowego) milczenia ${ }^{53}$. Chociaż nie pisała (między innymi z powodu przestrzegania Reguły Karmelu $)^{54}$, to jednak spotykała się ze swoim pierwszym kierownikiem duchowym, udając się do niego w duchową podróż z Chrystusem i w Chrystusie. Zaraz na początku listu pisze: „nasze obcowanie jest w niebie”. W zdaniu tym, pisanym po francusku, nie stosuje jak poprzednio rzeczownika „vie” (,życie”), ale „conversation” („rozmowa”, „konwersacja”). Parafrazując ${ }^{55}$ Flp 3,20, eksponuje miejsce spotkań z ks. kanonikiem — w niebie, czyli tam, gdzie jest Chrystus.

Siostra Elżbieta od Trójcy Świętej także w tym liście postrzega Pawłową myśl z Flp 3,20 jako coś już aktualnego. W dalszych wersetach swojego listu nie będzie już rozwijać tej kwestii, ale po życzeniach noworocznych podejmie jeszcze dwa kluczowe w jej duchowości zagadnienia: pragnienie pocieszania Jezusa, będąc bez przerwy z Nim zjednoczoną, oraz pragnienie bycia dla Jezusa jakby dodatkowym człowieczeństwem.

W liście tym nie zabrakło również informacji dotyczących mamy, siostry Małgorzaty i jej dwóch córek. Z okazji zbliżającej się trzeciej rocznicy profesji zakonnej (11 stycznia), poprosi także o modlitwę w swojej intencji, podczas celebrowania w tym dniu przez ks. kanonika Mszy św., oraz o ojcowskie błogosławieństwo.

50 Tekst oryginału: ,notre conversation est dans les Cieux” (L 256).

${ }^{51}$ Emilian Izydor Angles (1838-1923), ksiądz kanonik w Carcassonne. Przedtem był proboszczem w Saint-Hilaire, gdzie matka Elżbiety — Maria Catez z domu Rolland — zamieszkała z rodzicami (miała wtedy 16 lat). Prawdopodobnie ks. Angles był jej ówczesnym spowiednikiem. W późniejszych latach pani Catez wraz z córkami regularnie go odwiedzała; por. L 92, przyp. 1. Zob. fotografię ks. Angles'a w: Elżbieta od Trójcy Świętej. O świcie Ciebie szukam ..., s. 35, nr 106.

${ }^{52}$ To on pierwszy usłyszał pragnienie ośmioletniej Elżbiety Catez, by zostać zakonnicą; zob. C. De Meester, Święta Elżbieta od Trójcy Świętej. Biografia, thum. K. Rogalska, Poznań 2015, s. 59. O jej relacjach z ks. Angles'em zob. D. Kornas-Biela, Rodzinność w życiu i pismach bł. Elzbiety od Trójcy Świętej [w:] Rodzina u świętych Karmelu. XV Dni Duchowości. 10-11 maja 2012, red. J.W. Gogola, (Karmel Żywy 16), Kraków 2013, s. 61-101, tu: s. 94-99.

${ }_{53}$ Poprzedni list (L 232) do ks. kan. Angles'a siostra Elżbieta napisała 1 czerwca 1905 roku. L 258 jest datowany na koniec grudnia 1905 roku.

${ }_{54}$ Zob. Korespondencja w Karmelu w: Elżbieta od Trójcy Świętej, Pisma wszystkie, t. III, s. 471.

${ }_{55}$ Możliwy przekład tekstu siostry Elżbiety: „,nasze rozmowy są w niebie”. 


\section{7. „Nasze obcowanie jest w niebie"56 (L 339)}

To ostatni list Elżbiety od Trójcy Świętej, w którym znalazła się myśl z Flp 3,20. Mistyczka z Dijon od końca marca 1906 roku jest już w infirmerii klasztoru karmelitanek. Cierpi na nieuleczalną wówczas chorobę Addisona, która uniemożliwia jej przyjmowanie praktycznie wszystkich pokarmów ${ }^{57}$.

Adresatką listu była siostra Maria Otylia ${ }^{58}$. To list pożegnalny, pełny ufności wobec tego, co może wydarzyć się w najbliższych dniach, jak i list troski o współsiostrę z karmelitańskiej rodziny. Mistyczka z Dijon, oczekując na zbliżające się przejście do Domu Ojca ${ }^{59}$, zobowiązuje siostrę Marię Otylię do stałych spotkań w Ognisku miłości ${ }^{60}$, gdzie będzie upływać jej wieczność, a do której siostra Maria jeszcze przez pewien czas będzie się przygotowywać na ziemi. Siostra z Paray-le-Monial otrzymuje również zapewnienie od swojej młodszej współsiostry o stałym pomaganiu jej w ziemskiej wędrówce, a w razie potrzeby również o możliwości siostrzanego upomnienia („,przywołanie do porządku").

Wycieńczona chorobą Elżbieta od Trójcy Świętej kończy list prośbą o modlitewne wsparcie, aby jak najlepiej przygotowała się „do wieczerzy godów Baranka", obiecując, że w przyszłości będzie także opiekować się adresatką listu podczas jej śmierci. Nie mając już sił i pozwolenia na dłuższe pisanie, podsumowuje swoje rozważanie słowami św. Pawła: „nasze obcowanie jest w niebie”, chcąc zdaniem tym przenieść ich dalsze spotkania do niebiańskich komnat. Elżbieta ponownie korzysta $\mathrm{z}$ myśli zawartej w Flp 3,20 w łacińskiej formie przekładu, stosując rzeczownik „conversation”, w miejsce wcześniejszego „vie”.

56 Tekst oryginału: „notre conversation est dans les Cieux” (L 335).

57 Elżbieta była karmiona głównie mlekiem, czekoladą, cukierkami i lodami.

${ }^{58}$ Siostra Maria Otylia była bardzo dobrze znana siostrze Elżbiecie. Najpierw była siostrą turierką w Dijon, a następnie przez dwa miesiące siostrą konwerską wewnątrz klasztoru. Potem wyjechała na nową fundację w Paray-le-Monial. Elżbieta od Trójcy Świętej pisała do niej wielokrotnie. Zachował się jednak tylko ten jeden list. Siostra Maria Otylia wyznała: „,spaliłam wszystkie jej listy, a zachowałam tylko ostatni. [...] Dlatego, że był ostatni”; zob. Elżbieta od Trójcy Świętej, Pisma wszystkie, t. II, s. 554, przyp. 1; C. De Meester, Święta Elżbieta od Trójcy Świętej..., s. 439-440.

59 Nastąpi ono za dwanaście dni (9 listopada 1906 roku).

${ }^{60}$ Metafora „ogniska”, odzwierciedlająca miłość Boga, wielokrotnie była stosowana przez siostrę Elżbietę, zwłaszcza w pismach z ostatniego etapu jej ziemskiego życia; zob. np: „Ognisko miłości” (L 272; 306; 334; 339; 341; Poezje 95; 101; 102; 107); „Ognisko światła” (Poezja 86); „olbrzymie Ognisko” (L 295); , wielkie Ognisko” (L 318); „płonące Ognisko” (Poezja 103); „Ognisko Jego Miłości” (L 291); ,płonący Ogień miłości” (L 289); „Ognisko Bożej Miłości” (Poezja 95); „Ogień pochłaniający” (L 295). 


\section{8. „Nasze życie jest w niebie" ${ }^{\text {(ZD }}$ (Z)}

Elżbieta od Trójcy Świętej siedmiokrotnie posłużyła się myślą św. Pawła „nasze życie/obcowanie jest w niebie" w swoich listach, a tylko jeden raz poza nimi. Zamieściła to zdanie w osobistych „Zapiskach duchowych”"2. „Zapiski”, które zawierają interesującą nas wypowiedź, stanowią odzwierciedlenie osobistych rekolekcji, które siostra Elżbieta odprawiła pomiędzy 9 a 18 października 1905 roku. Trzon jej zapisu stanowi refleksja nad Listem do Filipian 3,8-10.12-14 (Chrystus najwyższą wartością; nieustanny bieg do celu, którym jest trwanie przy Bogu w niebie). W tym kontekście podejmuje krótką refleksję nad „stanem śmierci, który oddaje stworzenie Stwórcy”. Określa go jako „błogosławiony stan", który próbuje opisać za pomocą zdań zaczerpniętych z Pawłowych listów: „«umarliście bowiem i wasze życie jest ukryte z Chrystusem w Bogu» (Kol 3,3), albo jeszcze lepiej: «nasze życie jest w niebie» (Flp 3,20), wszystkie jego władze są skierowane na Boga; ono drga tylko pod tajemniczym dotknięciem Ducha Świętego, który je przemieni w «sławę chwały, do której zostało ono przeznaczone dekretem Tego, który dokonuje wszystkiego zgodnie z zamysłem swej woli» (por. Ef 1,11-12)".

Mistyczka z Dijon, patrząc z pasją w niebiańską przyszłość, w swoich przemyśleniach zatrzymuje się na chwili obecnej, w której człowiek przez uwielbienia, adoracje i hołdy oddawane Bogu dysponuje możliwością „,wkorzeniania się w Byt Boży". Człowiek, wędrując przez ziemskie życie, jest ukierunkowany na cel, jakim jest niebo, by ostatecznie mógł on w pełni uczestniczyć w świętości swojego Stwórcy.

\section{Podsumowanie}

Elżbieta od Trójcy Świętej była nie tylko uważną czytelniczką listów św. Pawła, ale przede wszystkim w swoim życiu starała się urzeczywistniać zawarte w nich natchnione myśli. Wymownym tego przykładem jest jej „drugie imię” zakonne: „Laudem gloriae” (Ef 1,12), które odzwierciedlało jej pragnienia duchowe i styl życia.

Jej ukierunkowanie czasowe, zarówno teraźniejsze, jak i przyszłe, bardzo dobrze obrazuje zdanie z Listu św. Pawła do Filipian „nasza ojczyzna jest w niebie" $(3,20)$. Dla Apostoła Narodów myśl ta stanowiła formę umocnienia chrześcijan w Filippi, którzy stając się wyznawcami Chrystusa, często byli

${ }^{61}$ Tekst oryginału: „notre vie est dans les Cieux” (NI 16).

${ }^{62}$ Zob. Elżbieta od Trójcy Świętej, Pisma wszystkie..., t. III, s. 289-323. Nie były one pisane dla kogoś. Zawierają myśli Elżbiety, często spisywane przez nią na „przypadkowych” materiałach piśmienniczych, pomiędzy kwietniem 1894 a lipcem 1906 roku. 
narażeni na utratę tego wszystkiego, co mogło być ważne w oczach ludzi im współczesnych (pozycja społeczna, prawa obywatelskie). W kontekście sytuacji w Filippi (aktywność błędnowierców) sformułowanie „nasza ojczyzna jest w niebie" to także wezwanie chrześcijan do jedności i wytrwałości. Wskazuje ono na głęboki związek pomiędzy aktualnym życiem ziemskim a przyszłym w ojczyźnie niebiańskiej. Dzięki dziełu odkupienia dokonanemu przez Jezusa Chrystusa człowiek otrzymał zaproszenie do życia wiecznego przy Bogu. Wspólnota zawiązana z Nim na ziemi swoją pełną realizację znajdzie w niebie (zob. Flp 3,20-21).

W pismach Elżbiety od Trójcy Świętej zagadnienie „niebiańskiej ojczyzny” pięciokrotnie otrzymało formę „notre vie est dans les Cieux” („nasze życie jest w niebie") [L 237; 241; 246; 249; ZD 16]. Raz zostało zapisane w języku łacińskim „nostra autem conversatio in coelis est” („Nasze zaś obcowanie/wspólny pobyt jest w niebie") [L 252], a dwukrotnie w wersji ,notre conversation est dans les Cieux” („nasze obcowanie jest w niebie”) [L 258; 339]. Mistyczka z Dijon zamienia rzeczownik „vie” (,życie”) na „,conversation” (,rozmowa”, „konwersacja") dopiero w dwóch ostatnich listach, w których znalazło się nawiązanie do Flp 3,20. Obydwa zostały napisane po L 252, w którym to siostra Elżbieta zacytowała interesujący nas fragment Listu do Filipian w wersji łacińskiej. Można przypuszczać, że zbliżony do łacińskiego słowa „conversatio” francuski termin „conversation”, lepiej wyrażał w tym okresie jej życia to, co chciała przekazać swoim adresatom.

Elżbieta od Trójcy Świętej dwukrotnie zamieściła sformułowanie „,nasze życie jest w niebie" jako nagłówek (motto) listu, jednakże nie rozwijając już dalej tej myśli. To listy pierwszy (L 237) i trzeci (L 246), gdzie odniosła się do Flp 3,20. We wszystkich pozostałych pismach myśl ta znalazła się w głównej ich części.

W okresie swojego pobytu w infirmerii, w której młoda karmelitanka spędziła ostatnie miesiące życia, tylko jeden raz wykorzystała to Pawłowe sformułowanie (L 339). List ten stanowi pożegnanie, a zawarta w nim wypowiedź „,nasze obcowanie jest w niebie" podsumowuje eschatologiczne rozważania wycieńczonej chorobą autorki. W żadnym z pozostałych pism siostra Elżbieta nie łączy bezpośrednio myśli z Flp 3,20 ze swoją śmiercią, ale wskazuje na głęboką jedność między życiem ziemskim, zakorzenionym w wierze w Jezusa Chrystusa, a życiem w wieczności, w którym spotkamy oczekującego nas Boga. W Nim też spotkamy tych, którzy z nami wędrowali przez życie.

Mistyczka z Dijon, przekazując swoim najbliższym stwierdzenie „nasze życie/obcowanie jest w niebie", które przed laty usłyszeli od Apostoła Pawła chrześcijanie w Filippi, chciała ich umocnić i zachęcić do wytrwałości w podążaniu już tu na ziemi drogą, która będzie ich wspólna w wieczności. Umacniając słowami Pawła innych, adresowała je również do siebie (ZD 16). 


\section{The Issue of 'Homeland in Heaven' in Paul's Letter to the Philippians and the Writings of Saint Elisabeth of the Holy Trinity}

\section{Summary}

The article is a study of the theme of 'heavenly homeland' in St. Paul's Letter to the Philippians 3:20 and in the writings of the French Carmelite St. Elisabeth of the Holy Trinity (1880-1906).

The first part is an exegesis of Phil 3:20. It consists of a description of the community in Philippi at the time when the Letter to the Philippians was written; suggestion of a translation of Phil 3:17-21 into Polish; general presentation of the context Phil 3:20 and discussion of the meaning of the lexeme politeuma.

The second part presents eight writings of Elizabeth of the Holy Trinity (Letters 237; 241; 246; 249; 252; 258; 339; Spiritual Notes [originally Notes intimes] 16), in which she made reference to the thought included in Phil 3:20.

The mystic from Dijon, a faithful and eager pupil of Paul the Apostle drew profusely from his inspired thoughts not only for herself but also shared them with others, as evidenced by several references to Phil 3:20 in her writings. Her aim was to strengthen those closest to her (and herself) in following here on Earth the way which would be their common way in eternity.

Translated by Patrycja Tomaszewska

\section{Keywords}

Letter to the Philippians 3:20, Elisabeth of the Holy Trinity, heaven, homeland, eternal life

\section{Slowa kluczowe}

List do Filipian 3,20, Elżbieta od Trójcy Świętej, niebo, ojczyzna, życie wieczne

\section{Bibliografia}

\section{Dotycząca Listu do Filipian}

Biblia Sacra iuxta vulgatam versionem, ed. B. Fischer, I. Gribomont, H.F.G. Sparks, W. Thiele, R. Weber, R. Gryson, Stuttgart 19944.

Novum Testamentum Graece, ed. E. Nestle, E. Nestle, B. Aland, K. Aland, J. Karavidopoulos, C.M. Martini, B.M. Metzger, Stuttgart $2012^{28}$.

Septuaginta. Id est Vetus Testamentum graece iuxta LXX interpretes, ed. A. Rahlfs, Stuttgart $1979^{2}$.

Bianchini F., L'elogio di sé in Cristo. L'utilizzo della periautologi, a nel contesto di Filippesi 3,1-4,1, (Analecta Biblica 164), Roma 2006.

Böttger P.Ch., Die eschatologische Existenz der Christen. Erwägungen zu Philipper 3,20, „Zeitschrift für die neutestamentliche Wissenschaft und die Kunde des Urchristentums" 60 (1969), s. 244-263.

Byrne B., List do Filipian [w:] Katolicki komentarz biblijny, red. nauk. wyd. oryginalnego R.E. Brown, J.A. Fitzmyer, R.E. Murphy, red. nauk. wyd. polskiego W. Chrostowski, thum. K. Bardski i inni, (Prymasowska Seria Biblijna 17), Warszawa 2001, s. 1399-1408. 
Dąbrowski E., Święty Pawet. Życie i pisma, Poznań $1952^{2}$.

Dibelius M., Die Briefe des Apostels Paulus. An die Thessalonicher I. II. An die Philipper, (Handbuch zum Neuen Testament III/2), Tübingen 1911.

Fee G.D., Paul's Letter to the Philippians, (The New International Commentary on the New Testament), Grand Rapids (MI)-Cambridge 1995.

Flis J., List do Filipian. Wstęp, przekład z oryginału, komentarz, (Nowy Komentarz Biblijny. Nowy Testament XI), Częstochowa 2011.

Hawthorne G.F., Martin R.P., Philippians, (Word Biblical Commentary 43), Nashville $2004^{2}$.

Jankowski A., Listy więzienne świętego Pawła. Do Filipian - do Kolosan - do Filemona - do Efezjan. Wstęp, przektad z oryginatu, komentarz, (Pismo Święte Nowego Testamentu VIII), Poznań 1962.

Langkammer H., List do Filipian. Ttumaczenie, wstęp i komentarz, (Biblia Lubelska), Lublin 2001.

Mędala S., Świadectwo mocy Chrystusa (List do Filipian) [w:] Wprowadzenie w myśl $i$ wezwanie ksiag biblijnych, t. IX: Dzieje Apostolskie. Listy św. Pawła, red. J. Frankowski, współred. S. Mędala, Warszawa 1997, s. 381-411.

Miller E.C., Politeu,esqe in Philippians 1,27: Some philological and thematic observations, „Journal for the Study of the New Testament" 15 (1982), s. 86-96.

Müller U.B., Der Brief des Paulus an die Philipper, (Theologischer Handkommentar zum Neuen Testament 11/I), Leipzig 2002².

Pilhofer P., Philippi, Bd. I: Die erste christliche Gemeinde Europas, (Wissenschaftliche Untersuchungen zum Neuen Testament 87), Tübingen 1995.

Pilhofer P., Philippi, Bd. II: Katalog der Inschriften von Philippi, (Wissenschaftliche Untersuchungen zum Neuen Testament 119), Tübingen 2000.

Portefaix L., Sisters Rejoice: Paul's Letter to the Philippians and Luke - Acts as Seen by First-Century Philippian Women, Uppsala 1988.

Wick P., Der Philipperbrief. Der formale Aufbau des Briefs als Schlüssel zum Verständnis seines Inhalts, (Beiträge zur Wissenschaft vom Alten und Neuen Testament 135), Stuttgart-BerlinKöln 1994.

Wilk J., List do Filipian. Wstęp, przekład z oryginału, komentarz, (Biblia Impulsy XI), Katowice 2017.

Wilk J., ,,Teologia kontaktu” na podstawie Listu św. Pawła do Filipian i Dziejów Apostolskich 16, (Studia i Materiały Wydziału Teologicznego Uniwersytetu Śląskiego w Katowicach 31), Katowice 2006.

Wilk J., Wartości figuralne metafor w Pawłowym Liście do Filipian (3,2), „Ateneum Kapłańskie” 162 (2014) 1(629), s. 95-104.

\section{Dotycząca Elżbiety od Trójcy Świętej}

Élisabeth de la Trinité, CEuvres Complètes, édition critique C. De Meester, Paris $2017^{3}$. Wydanie polskie: Elżbieta od Trójcy Świętej, Pisma wszystkie, t. I: Listy młodzieńcze; t. II: Listy z Karmelu; t. III: Pisma pomniejsze, przekł. i oprac. J.E. Bielecki, Kraków 2006.

Elżbieta od Trójcy Świętej. O świcie Ciebie szukam. Wspomnienie pewnego oblicza i pewnego serca, red. P.P. Furdzik, Kraków 2006.

Dąbek T.M., Biblia w duchowości bt. Elżbiety od Trójcy Przenajświętszej [w:] „Uwielbienie chwaty”. VI Karmelitański Tydzień Duchowości z bt. Elżbieta od Trójcy Świętej. 5-8 maja 2003, red. J.W. Gogola, (Karmel Żywy 6), Kraków 2004, s. 33-49. 
De Meester C., Święta Elżbieta od Trójcy Świętej. Biografia, przekł. K. Rogalska, Poznań 2015.

Kornas-Biela D., Rodzinność w życiu i pismach bt. Elżbiety od Trójcy Świętej [w:] Rodzina u świętych Karmelu. XV Dni Duchowości. 10-11 maja 2012, red. J.W. Gogola, (Karmel Żywy 16), Kraków 2013, s. 61-101.

Kraj K.W., Laudem gloriae — życie codzienne jako liturgia [w:] ,,Uwielbienie chwały”. VI Karmelitański Tydzień Duchowości z bt. Elżbieta od Trójcy Świętej. 5-8 maja 2003, red. J.W. Gogola, (Karmel Żywy 6), Kraków 2004, s. 155-181.

L'abbé André Chevignard, 3 października 2017, [online] http://www.elisabeth-dijon.org/fr/accueil/95-cat\%C3\%A9gories-all/cat\%C3\%A9gories-fr/personnes/259-abb\%C3\%A9-chevignard. html [15.11.2018].

Miczyński J.K., La lettura spirituale dell'insegnamento di San Paolo Apostolo negli scritti di Elisabetta della Trinità, „Spiritualitas” 1 (2014), s. 217-230.

Nawracała T., Les fines dernières chez la b. Elisabeth de la Trinité, „Wrocławski Przegląd Teologiczny" 17 (2009) 2, s. 61-76.

Nawracała T., Louange de la gloire — la vie de l’homme cachée dans la Trinité, „Poznańskie Studia Teologiczne" 24 (2010), s. 215-234.

Philipon M.M., Trójca Święta w moim życiu. Doktryna duchowa Siostry Elżbiety od Trójcy Przenajświętszej, thum. siostra dominikanka z klasztoru św. Anny, siostra benedyktynka od nieustającej adoracji, Poznań $2002^{2}$.

Rémy J., Guite. La sorella di Elisabetta della Trinità, trad. L. Ceccon Terranova, Milano 2004.

Sicari A.M., Elżbieta od Trójcy Świętej, tłum. A. Bałucka-Grimaldi, Kraków 2007.

Szczurek J.D., Tajemnica zamieszkania Trójcy Świętej w duszy wedlug bł. Elżbiety w Dijon [w:] Niebo w mej duszy. Materiały z sympozjum poświęconego duchowości bł. Elżbiety od Trójcy Świętej (1880-1906) w stulecie jej śmierci. Kraków, 21 listopada 2006 r., red. A. Ruszała, Kraków 2007, s. 27-44.

Vella A., Bl. Elizabeth of the Trinity: Disciple of St. Paul, „Carmel in the World” 24 (1985), s. 207-216.

\section{Dziela różne}

Do Diogneta [w:] Pierwsi świadkowie. Pisma Ojców Apostolskich, thum. A. Świderkówna, wstęp, kom. i oprac. M. Starowieyski, (Biblioteka Ojców Kościoła 10), Kraków $2010^{2}$ (uzupełnione i poprawione), s. 334-350.

Hutter U., politeuma [w:] Exegetisches Wörterbuch zum Neuen Testament, hrsg. v. H. Balz, G. Schneider, Bd. III, Stuttgart-Berlin-Köln 1992², kol. 310-312.

Popowski R., Wielki słownik grecko-polski Nowego Testamentu. Wydanie z petna lokalizacja greckich haset, kluczem polsko-greckim oraz indeksem form czasownikowych, (Prymasowska Seria Biblijna 3), Warszawa $1995^{2}$.

Słomka J., Metodologia teologii duchowości, „Śląskie Studia Historyczno-Teologiczne” 50 (2017) 1, s. 129-142.

Slownik grecko-polski, t. III, red. Z. Abramowiczówna, Warszawa 1962.

Słownik łacińsko-polski, t. I, red. J. Korpanty, Warszawa 2001.

Świderkówna A., Biblia w świecie greckim, (Radiowa Katecheza Biblijna 5), Gniezno 1996. 